\title{
Tracking juvenile fish movement and nursery contribution within arid coastal embayments via otolith microchemistry
}

\author{
F. Joel Fodrie ${ }^{1,3, *}$, Sharon Z. Herzka ${ }^{2}$ \\ ${ }^{1}$ Integrative Oceanography Division, Scripps Institution of Oceanography, Mail Code 0218, La Jolla, \\ California 92093-0218, USA \\ ${ }^{2}$ Departamento de Oceanografia Biológica, Centro de Investigación Científica y de Educación Superior de Ensenada (CICESE), \\ Km 107 Carretera Tijuana-Ensenada, 22860 Ensenada, Baja California, Mexico \\ ${ }^{3}$ Present address: Dauphin Island Sea Lab, 101 Bienville Blvd, Dauphin Island, Alabama 36528, USA
}

\begin{abstract}
An increasingly common approach for examining the movement of fish involves elemental fingerprinting, which exploits variation in the chemical composition of otoliths induced by environmental gradients. We assessed the elemental signatures of recently deposited material in the otoliths of juvenile California halibut Paralichthys californicus collected from different zones along the main axis of coastal embayments of southern California, USA, and Baja California, Mexico. From these data, we determined if unique chemical signals within embayments allowed for the reconstruction of movement patterns over small scales. Juvenile halibut were collected during 3 years (2001 to 2003) along 2 segments of coastline, including 4 embayment and 3 exposed habitats. We also compared otolith chemistry from wild-caught and caged halibut in the Punta Banda Estuary, Baja California, Mexico, and Mission Bay, California, USA; within both locations, we observed increasing concentrations of $\mathrm{Mn}$ and $\mathrm{Ba}$ in the otoliths of wild-caught and caged juveniles collected farther within embayments. However, only in Punta Banda did we find strong congruence between otolith signals from wild-caught and caged individuals. Hence, we exploited the intra-embayment variability in otolith microchemistry to chart 2 forms of movement of juvenile halibut within Punta Banda. First, within-embayment movements of juvenile fish were examined over 2 mo. Over this timescale, 8 of 14 individuals had moved among embayment zones. Second, the contribution of different embayment zones to production of adult biomass was determined. The vast majority of juveniles (82 to $89 \%$, $\mathrm{n}=27$ ) that advanced to older age classes during 2002 and 2003 occupied the middle and outer zones of Punta Banda. Recognition of intra-embayment variability in otolith signals from southern and Baja California should allow for finer-scale analyses of habitat utilization, and more thorough examination of connectivity resulting from the ontogenetic migration of fish from juvenile to adult habitats.
\end{abstract}

KEY WORDS: Nursery habitat contribution · Otolith microchemistry · Embayment · California halibut · Paralichthys californicus · Caging

\section{INTRODUCTION}

The ability to track movement patterns of fish with complex life cycles in which larvae, juveniles and adults exploit different habitats is necessary for estimating habitat 'value' in terms of fishery production
(Beck et al. 2001). Calculating the degree of connectivity between habitats, or among spatially separated nearshore juvenile populations and offshore adult populations, also has direct implications for stock and habitat conservation, as well as for understanding of metapopulation and evolutionary processes (Secor \& 
Rooker 2005). In recent years, trace element analyses of otoliths (ear stones) have been employed to determine the origin of marine fishes egressing from putative nurseries (Gillanders \& Kingsford 1996, Yamashita et al. 2000, Gillanders 2002a). Because trace elements are incorporated into otoliths during growth in a manner that reflects the ambient conditions experienced by individuals, they serve as natural markers of residence and movement over a variety of spatial scales (Campana 1999). The capacity to identify the appropriate spatial and temporal scales over which to exploit elemental signal variation in otoliths will ultimately determine the resolution of future tracking studies that employ this approach.

A number of studies have examined nursery use along coastlines that receive large amounts of freshwater input, and include complex wetland and estuarine habitats extending over hundreds of square kilometers (Secor 1992, Thorrold et al. 1998a, Kraus \& Secor 2005). Researchers working in these systems have taken great care to document the incorporation of trace elements into otoliths as a function of elemental concentrations in water, salinity, temperature and fish growth rate (Fowler et al. 1995, Secor et al. 1995), as well as assessing intra-embayment variability in otolith composition (Thorrold et al. 1998b). At the other extreme of the gradient in freshwater inflow, southern California estuarine habitats are seasonally or permanently hypersaline and often small in size (Zedler 1982). Studies of nursery contribution along this type of coastline have generally considered entire embayments as the nursery unit and typically have not reported on intra-embayment variability in otolith microchemistry or nursery contribution (Forrester \& Swearer 2002, Swearer et al. 2003, Brown 2006a).

Libraries of chemical fingerprints that represent potential nurseries are typically generated by collecting residents from target habitats and analyzing the elemental composition of their otoliths (e.g. Gillanders 2002b, Hanson et al. 2004, Brown 2006b). An implicit assumption made in these studies is that captured fish have resided near their collection sites for sufficiently long to reflect local conditions. This may be a reasonable assumption if collection sites are separated by 10 to $100 \mathrm{~km}$ (see discussion in Brown 2006b). However, it may be violated for nearby collection sites if there is short-term, small-scale movement of fish. Outplanting and incubating specimens in enclosures ensures that fish have not immigrated immediately preceding their collection (Kraus \& Secor 2004, Forrester 2005, Becker et al. 2007).

Our goal was to evaluate the feasibility of exploiting small-scale, within-embayment variation in otolith microchemistry to reconstruct the movement of juvenile California halibut Paralichthys californicus inside arid embayments of southern California, USA, and Baja California, Mexico. We attempted to track 2 forms of juvenile fish movement: (1) within-embayment movement over 2 mo and (2) the emigration of individual recruits from specific zones within embayments to sub-adult populations (thereby measuring the nursery role of each zone; Beck et al. 2001). A requisite for this investigation was documenting the spatial patterns of signal variation inside coastal embayments. In addition to collecting wild-caught fish, we incubated juvenile halibut in cages to better define small-scale gradients in elemental signals and to test for the presence of caging effects on otolith microchemistry.

\section{MATERIALS AND METHODS}

Model species. The California halibut is found in the coastal waters of western North America. Juveniles occupy shallow habitats along exposed coastlines or within protected embayments, where abundances are considerably higher (Kramer 1990). Halibut recruit to estuaries at 10 to $70 \mathrm{~mm}$ standard length (SL) and begin to emigrate at around $140 \mathrm{~mm}$ SL (Kramer 1991). In smaller embayments $\left(<0.25 \mathrm{~km}^{2}\right)$, abundance is highest near the mouth, while in larger systems $\left(>0.25 \mathrm{~km}^{2}\right)$, it tends to be highest toward the middle or inner reaches (Fodrie \& Mendoza 2006, LópezRasgado 2006). Kramer (1991) found that juvenile halibut within embayments tend to move deeper with age, regardless of distance from the embayment mouth. Together, these results suggest that halibut are capable of movement within individual embayments throughout the juvenile phase in response to local gradients in habitat quality or environmental conditions.

Study systems. We sampled juveniles in 3 embayments: the Punta Banda Estuary (PBE) in Baja California, Mexico, and Mission Bay (MB) and San Diego Bay (SDB) in southern California, USA (Fig. 1). We also sampled juveniles in nearby semi-exposed or exposed habitats to serve as 'embayment outliers': Todos Santos Bay (TSB) in Mexico, and La Jolla (LJ) and Imperial Beach (IB) in California. PBE is a relatively unmodified system that has a main channel $7.6 \mathrm{~km}$ long, a median depth of $5 \mathrm{~m}$ and a simple L-shaped footprint (Ortiz et al. 2003). It is connected to TSB by a single, narrow inlet. TSB is a semi-enclosed coastal system located $100 \mathrm{~km}$ south of the USA-Mexico border. Within TSB, there is suitable habitat for juvenile halibut along an $8 \mathrm{~km}$ long, semi-exposed beach and within the Port of Ensenada (Port En), a small harbor in the northeast corner of the bay artificially created by long rock jetties. MB is roughly a $3 \times 3 \mathrm{~km}$ square with an average depth of $5 \mathrm{~m}$. Several large dredge islands divide MB into multiple sections and marinas (Largier et al. 2003). 

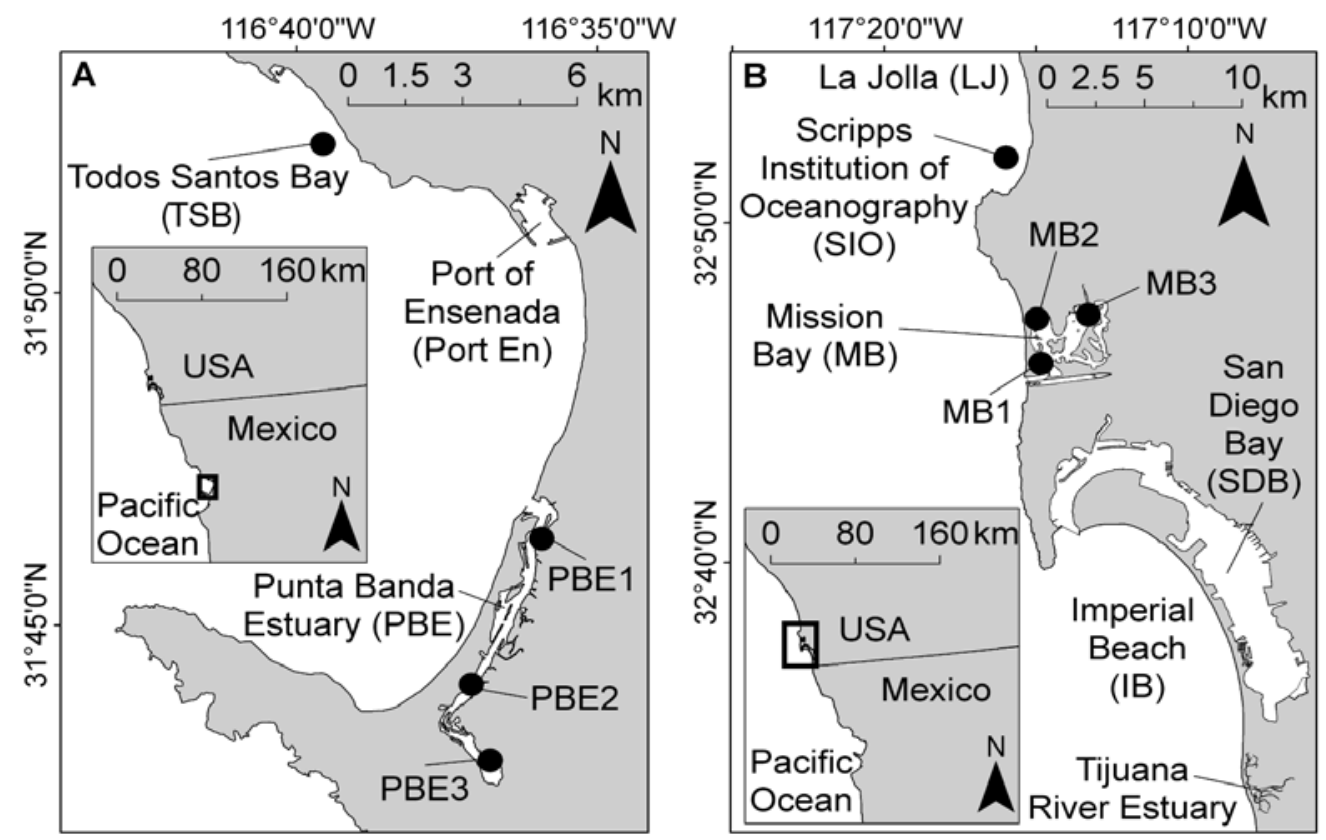

Fig. 1. Locations of juvenile halibut collections and caging experiments in (A) Baja California, Mexico, and (B) southern California, USA, with regional insets. Cages were deployed (๑) semi-annually during 2003 and 2004 within the Punta Banda Estuary and Mission Bay

SDB covers over $45 \mathrm{~km}^{2}$ with a mean depth of $12 \mathrm{~m}$ and has a J-shaped footprint. Outer SDB is deeper and serves as a major commercial and military port, while inner SDB is shallower, with less boating and shipping activity (US Department of the Navy, Southwest Division and San Diego Unified Port District 2000). Hereafter, we refer to PBE, TSB and Port En as our Baja California sites, and $\mathrm{MB}, \mathrm{SDB}, \mathrm{LJ}$ and IB as our southern California sites.

Field work. Intra-embayment variability of otolith microchemistry: To examine the coherence of otolith chemical signals among zones within embayments, we collected and analyzed the otoliths of wild-caught fish and performed outplanting experiments. Wild-caught fish (62 to $22 \mathrm{~mm}$ SL) were collected from the Baja California sites in $2002(n=53)$ and $2003(n=87)$, and from the southern California sites in $2001(n=84)$. Juveniles were collected in the outer, middle and inner sections of PBE (PBE1, PBE2 and PBE3, respectively), and in the inner and outer halves of $\mathrm{MB}$ and SDB. Collections were made in October and November of all 3 years, using an otter trawl. We included at least 10 fish from every site in our analyses, except from the semiexposed beach in TSB $(n=6)$ and Port En $(n=7)$ in 2002.

During the spring and fall of 2003 and 2004, we caged fish in PBE1, PBE2, PBE3 halves of as well as in the outer (MB1), middle (MB2) and inner (MB3) sections of MB (Fig. 1). Cages were also deployed in TSB near the Centro de Investigación Científica y de Educación Superior de Ensenada and adjacent to the Scripps Institution of Oceanography Pier (SIO) to serve as 'embayment outliers' for PBE and $M B$, respectively (Fig. 1). Two $0.5 \mathrm{~m}^{3}$ cages were deployed at each site during every trial, except at SIO, where 3 cages were deployed. Cages were constructed with $6 \mathrm{~mm}$ VEXAR mesh, 1 inch $(2.54 \mathrm{~cm})$ PVC piping and marine cable ties. We avoided using metal in cages and leached all the components in seawater tanks for 2 mo to reduce potential otolith contamination. Several sand bags filled with sediment from the caging sites were used to stabilize cages. Cages were placed sub-tidally and allowed to settle for several days before juveniles were outplanted.

Juveniles (79 to $121 \mathrm{~mm}$ SL) used for caging were collected from PBE2 (PBE cages) and the Tijuana River Estuary (MB cages; Fig. 1) and held in laboratory tanks for 2 to $3 \mathrm{~d}$. One day before outplanting, we marked the otoliths by immersing halibut in alizarin complexone blue (ACB) dye (>30 ppb) for $12 \mathrm{~h}$ (as per Elsdon \& Gillanders 2005). Four juveniles were placed in each cage, and cages were sewn shut. Cages were regularly checked for debris and positioning, but otherwise remained undisturbed until fish were recovered after 2 mo. Several cages were lost due to high flow-rates within the embayments, coupled with the absence of metal components to anchor or strengthen the cages. As a result, we only recovered enough caged individu- 
als to examine intra-embayment variability in PBE in March-April 2004 (n = 24) and MB during SeptemberOctober 2003 ( $\mathrm{n}=25)$.

Comparison of caged vs. wild-caught fish otolith microchemical signals: To test the utility of outplanting fish to generate site-specific reference signatures for reconstructing small-scale movements, we compared the chemical signals in the otoliths of caged and wild-caught fish from the same location. Wild-caught halibut were collected by otter trawling in the vicinity of cages on the same day outplanted fish were recovered ( $\mathrm{n}=27$ in $\mathrm{PBE}, \mathrm{n}=18$ in $\mathrm{MB}$ ). All caged and wildcaught juveniles included in these comparisons were 80 to $115 \mathrm{~mm}$ SL.

Nursery contribution of embayment zones: The elemental composition of the otoliths of juvenile halibut collected in the TSB system in 2002 and 2003 were used to generate a reference set of habitat-specific chemical fingerprints representing all potential nurseries for juvenile halibut in the area (PBE1, 2, and 3; TSB; Port En). In 2005, we collected sub-adult halibut ( 2 and 3 yr old fish; 271 to $388 \mathrm{~mm} \mathrm{SL}$ ) from TSB directly from local fishermen $(n=27)$ and were able to infer nursery habitats by comparing their juvenilestage otolith signals to the reference set.

Our strategy assumed that the post-larval population within our Baja California sites operated as a closed system (i.e. we chemically defined all potential nurseries). North and south of our Baja sites, the coastline is rocky, highly exposed and unsuitable for juvenile halibut (Fodrie \& Mendoza 2006). Also, a recent year-long survey found that the nearest sandy shoreline in the region (ca. $45 \mathrm{~km}$ north) exhibited extremely low abundance of juveniles compared to that found within PBE, Port En and TSB (S.Z. Herzka unpubl. data). Tagging studies have demonstrated that juvenile and adult halibut exhibit very limited latitudinal movement (e.g. Posner \& Lavenberg 1999) and, therefore, would be unlikely to immigrate into our Baja Californis sites from other nurseries, as the closest estuaries (aside from PBE) are the Tijuana River Estuary (100 km north) and San Quintin Bay (170 km south).

Otolith analyses. Sagittal otoliths were dissected using sterile scalpels and ceramic forceps. Otoliths were sonicated for $5 \mathrm{~min}$ in $15 \% \mathrm{H}_{2} \mathrm{O}_{2}$ buffered with $0.05 \mathrm{~mol} \mathrm{l}^{-1} \mathrm{NaOH}$, then for $5 \mathrm{~min}$ in $3 \% \mathrm{HNO}_{3}{ }^{-}$and rinsed with Milli-Q to remove attached organics. We mounted otoliths in crazy glue on petrographic slides, sanded them along the sagittal plane using 30 and 3 $\mu \mathrm{m}$ lapping paper, and polished them with a wet rock cloth (Secor et al. 1991). Mounted otoliths were given additional 5 min washes in $15 \% \mathrm{H}_{2} \mathrm{O}_{2}$, then $3 \%$ $\mathrm{HNO}_{3}{ }^{-}$and finally rinsed 3 times with Milli-Q before being dried and stored in a laminar flow hood. All containers, slides and forceps were rinsed with $3 \%$
$\mathrm{HNO}_{3}{ }^{-}$before contact with otoliths. We examined sagittal otoliths from the blind side of fish to ensure that all samples were recording from the same environment (the sediment interface). Since this species can be left- or right-eyed, the otolith we selected varied among individuals.

We sampled specific growth rings using a New Wave UP $213 \mathrm{~nm}$ laser ablation unit. Otoliths were sampled by ablating a $300 \mu \mathrm{m}$ line parallel to targeted growth increments at ca. $0.5 \mathrm{~mJ}$ intensity, $15 \mu \mathrm{m} \mathrm{s}{ }^{-1}$ scan speed and a $20 \mu \mathrm{m}$ spot size. Post-run inspection of 10 haphazardly selected otoliths revealed that ablations could range between 20 and $35 \mu \mathrm{m}$ wide, and between 8 and $14 \mu \mathrm{m}$ deep. Since the average daily increment width in juvenile otoliths is ca. $3 \mu \mathrm{m}$ (Kramer 1991), we sampled roughly 2 wk of growth per ablation. Ablated material was transported using He gas (mixed with Ar) to a Thermoquest Finnigan Element 2 double-focusing, single-collector, magneticsector inductively coupled plasma mass spectrometer. Based on previous results of elemental fingerprinting of mussels collected from San Diego County (Becker et al. 2005), we sampled for the following isotopes to search for spatial discrimination: ${ }^{26} \mathrm{Mg},{ }^{48} \mathrm{Ca}$, ${ }^{55} \mathrm{Mn}$, ${ }^{63} \mathrm{Cu},{ }^{88} \mathrm{Sr},{ }^{135} \mathrm{Ba},{ }^{208} \mathrm{~Pb}$, and ${ }^{238} \mathrm{U}$ (hereafter referred to by elemental abbreviation). Data processing to generate elemental concentrations standardized to calcium (X:Ca) also followed Becker et al. (2005). Detection limits for each element were as follows: $0.02 \mathrm{mmol}$ $\mathrm{mol}^{-1}$ (Mg:Ca), <0.01 mmol mol${ }^{-1}$ (Mn:Ca), $0.1 \mu \mathrm{mol}$ $\mathrm{mol}^{-1}$ (Cu:Ca), $0.01 \mathrm{mmol} \mathrm{mol}{ }^{-1}$ (Sr:Ca), <0.01 mmol $\mathrm{mol}^{-1}(\mathrm{Ba}: \mathrm{Ca}), \quad<0.001 \mathrm{mmol} \mathrm{mol}^{-1}(\mathrm{~Pb}: \mathrm{Ca})$ and $0.001 \mu \mathrm{mol} \mathrm{mol}{ }^{-1}$ (U:Ca). A glass standard spiked with trace elements (National Institute of Standards and Technology Standard Reference Material, NIST 612; Pearce et al. 1997) was analyzed at the beginning and end of each day to account for machine drift. Over the range of juvenile lengths included in this study, there was no relationship between fish size and otolith microchemistry for any of the elements we considered (all $\left.\mathrm{r}^{2}<0.04\right)$. Also, we tested for differences in otolith length (as a proxy for fish length) among collection sites using 1-way ANOVAs on fish otoliths collected from our southern California sites in 2001 and fish otoliths collected from our Baja California sites in 2002 and 2003. There was no significant difference in otolith lengths among sites in either study system $(p>0.07$ in both cases). Based on these tests, we are confident that fish size did not confound our analyses.

Intra-embayment variability of otolith microchemistry. We ablated growth rings from the post-rostral margin (PRM) of juvenile otoliths collected during fall surveys from Baja California (2002 to 2003) and southern California (2001). Ablations were begun as close to the post-rostral apex as possible and progressed ven- 
trally along the margin, thereby sampling the most recent growth increments. The mean distance from the nucleus to the PRM was $1250 \mu \mathrm{m}$.

Comparison of caged vs. wild-caught fish otolith microchemical signals. The outplanted fish that were marked with ACB exhibited 3 distinct growth patterns during the caging period: (1) 80 to $100 \mu \mathrm{m}$ of normal growth increments from the ACB mark to the otolith margin; (2) 80 to $100 \mu \mathrm{m}$ of growth from the ACB mark to the otolith margin without visible incrementation; and (3) no apparent growth following the ACB mark. We excluded the third class from elemental analyses, but did include the otoliths with and without visible increments. On these otoliths, we sampled along the PRM as described above, but also sampled adjacent to the ACB mark (approximately $80 \mu \mathrm{m}$ inside the otolith edge). Hence, we obtained chemical signals corresponding to the period immediately before retrieval (PRM) as well as the period of time shortly after the caging began (PRM - $80 \mu \mathrm{m})$. The same growth rings (PRM and PRM - $80 \mu \mathrm{m}$ ) were sampled from wildcaught fish collected at the end of caging experiments ( $\mathrm{n}=14$ for PRM - $80 \mu \mathrm{m}$, since only fish from PBE with 2 mo of visible increments on the edge of otoliths were analyzed).

Nursery contribution of embayment zones. For the 2 and 3 yr old halibut collected from Baja California in 2005, we ablated material $1250 \pm 300 \mu \mathrm{m}$ from the otolith nucleus in the direction of the PRM. This range of distances allowed us to target what appeared to be fall growth based on opaque-hyaline banding. The ablations targeted otolith material deposited during the first year of the fish's life (as before, representing ca. 2 wk of growth), and could be compared to the signals from 2002-2003 juveniles to infer nursery habitat origin. Successive seasonal growth rings appeared to have 'elbows', indicating the approximate location of the PRM apex of earlier growth rings, which we used to position our ablations.

Statistical analyses. Intra-embayment variability of otolith microchemistry: Location-specific fingerprints were generated from the otoliths of wild-caught and caged juvenile halibut collected in the Baja and southern California sites to examine inter- and intraembayment variability in chemical signals. Element to calcium ratios (X:Ca) were analyzed using linear Discriminant Function Analysis (DFA; Systat 9, OSPSS). Cross-validation of each DFA model was achieved by re-classifying each sample using the jackknife method; each DFA was then compared to 4 replicates in which the collection sites of individual fish were randomly assigned (White \& Ruttenberg 2007). For southern California, we also quantified the ability of DFA algorithms to distinguish among putative nurseries by pooling zones within bays (inner vs. outer) and com- paring MB vs. SDB. We also used MANOVA to test for differences in otolith chemistry among collection sites for fish otoliths collected during the fall of 2001 (southern California) and in 2002-2003 (Baja California). For each of these analyses, only the elements that proved valuable in generating DFA algorithms were included as dependent variables in the MANOVAs.

Comparison of caged vs. wild-caught fish otolith microchemical signals: For caged fish to serve as useful proxies of site-specific signals, X:Ca ratios of the most recently deposited growth increments in the otoliths of caged and wild-caught fish collected simultaneously must not differ significantly. There must also be differences in the $\mathrm{X}: \mathrm{Ca}$ ratios in the otoliths of caged fish incubated in different locations. We used 2-factor ANOVAs (StatView 5.0.1, OSAS Institute) to test for effects of caging and embayment zone on the elemental composition of otoliths measured at the PRM. Parametric tests were used because $F_{\max }$ tests revealed no heteroscedasticity among groups. Separate analyses were conducted for $\mathrm{PBE}$ and $\mathrm{MB}$, and data from exposed sites were excluded. Only elements included in the DFAs generated from post-rostral ablations of the otoliths of caged fish were considered when testing for the significance of main effects. To reconstruct the prior movement (ca. 2 mo) of wildcaught halibut captured simultaneous to the retrieval of caged fish, DFA models were generated from the PRM - $80 \mu \mathrm{m}$ data sets obtained from fish caged in each of the 3 estuarine zones. We then compared the chemical signals of 14 wild-caught juveniles (PRM $80 \mu \mathrm{m})$ with those DFA models to assign past habitat utilization.

Nursery contribution of embayment zones: Juvenile halibut collected within PBE, TSB and Port En in 2002 and 2003 provided a reference set of habitat-specific chemical fingerprints representing all potential nurseries for juvenile halibut in the area (assuming a closed system). Using both DFA and Classification Trees (Breiman et al. 1984), we assigned nursery habitat origins for the 2 (relative to the 2003 library) and 3 yr old (relative to the 2002 library) sub-adults collected in 2005.

\section{RESULTS \\ Intra-embayment variability of otolith microchemistry}

We generated distinct fingerprints of individual collection sites using fish collected in 2002 and 2003 from the Baja California sites (Fig. 2). After stepwise elimination of element ratios (F-to-remove $<2$ ), $\mathrm{Mg}$, $\mathrm{Mn}, \mathrm{Sr}$ and $\mathrm{Ba}$ remained in the final DFA model for 


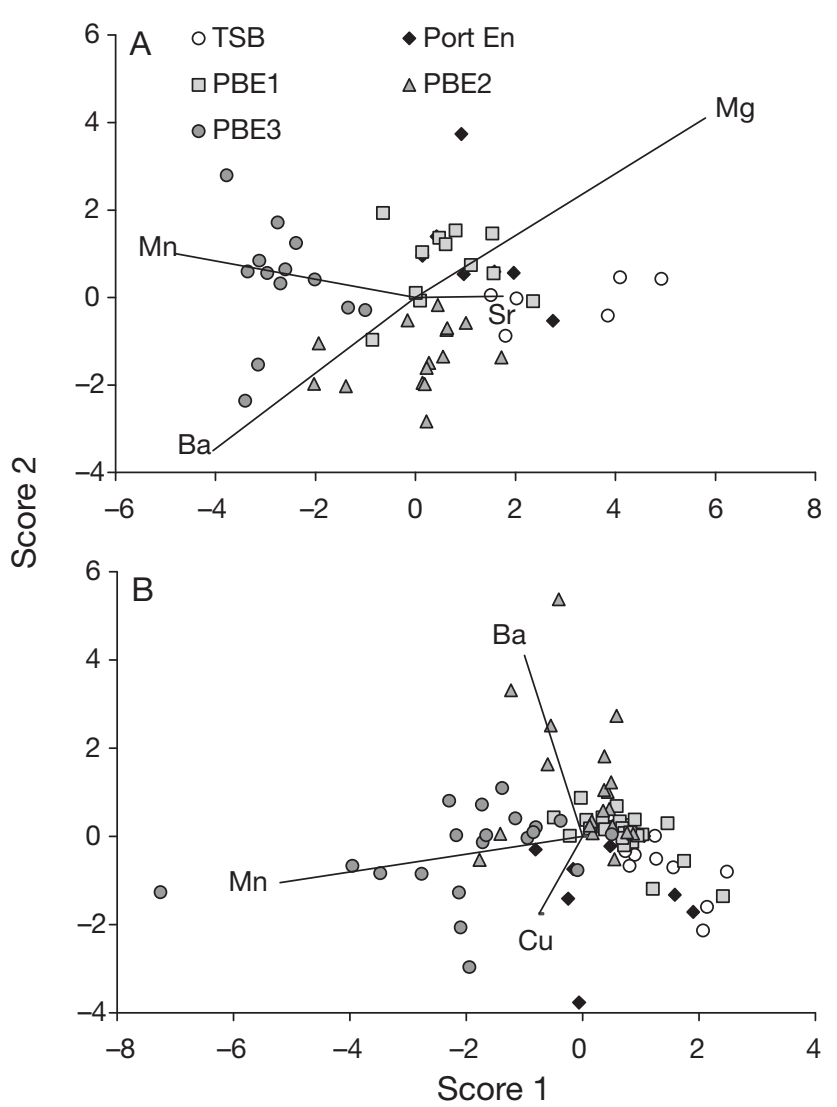

Fig. 2. Discriminant function analysis (DFA) scores of element:Ca ratios in otoliths of juvenile halibut collected during (A) fall 2002 and (B) fall 2003 within potential nursery habitats in Todos Santos Bay (TSB), Port of Ensenada (Port En), outer Punta Banda Estuary (PBE1), middle Punta Banda Estuary (PBE2) and inner Punta Banda Estuary (PBE3). Discriminant functions are standardized by within variances and scaled to overlay scatterplots for the element ratios used to create algorithms. Vectors represent the relative contribution of each element ratio to the resulting group scores

the 2002 data set and $\mathrm{Mn}, \mathrm{Cu}$ and $\mathrm{Ba}$ for the DFA corresponding to 2003 (Fig. 2). Overall classification success for the 5 sites was above $70 \%$ in both years (Table 1 ; compared to $<33 \%$ in cases with collection sites randomized). In both years, PBE3 was distinguishable from all other sites due to high $\mathrm{Mn}$ ratios and in 2002 by elevated Ba. PBE2 was also distinct from other sites, but appeared to be transitional in elemental composition between PBE3 and PBE1. In 2002, PBE1 signals overlapped with those of TSB and Port En, but in 2003 most individuals collected in PBE1 exhibited a distinct elemental signature (85\% classification accuracy) from other locations except for 6 specimens collected in PBE2 (Table 1).

Within the southern California sites, otolith signals from LJ and inner MB could be distinguished from all other sites we considered (Table 1). Conversely, signals from IB, outer MB and SDB showed considerable overlap (Table 1, Fig. 3). Stepwise elimination of element ratios left $\mathrm{Mn}$ and $\mathrm{Sr}$ in the final DFA model (Fig. 3). Overall classification success was only $49 \%$ in distinguishing among collection sites, compared to $21 \%$ for the cases with collection sites randomized. Pooling data from embayments based on zones (comparing inner vs. outer reaches of both $\mathrm{MB}$ and SDB) was as effective in maximizing overall classification success as classifying juveniles to individual bays (Table 1). For instance, MB and SDB specimens were correctly classified 83 and $44 \%$ of the time (63\% overall), respectively. Alternatively, inner and outer zones were classified with success rates of 91 and $44 \%$, respectively (61\% overall). Finally, all 3 MANOVAs that examined the differences in otolith chemistry among collection sites (Baja California in 2002 and 2003, southern California in 2001) indicated that there were highly significant differences in otolith chemistry ( $p<0.0001$ in every case).

There was also considerable spatial variability for the chemical signals in the otoliths of caged fish. Overall classification success in PBE was high based on PRM signals (96\%, compared to $39 \%$ in cases with caging sites randomized) and only 1 out of 24 fish was classified incorrectly (a PBE1 fish was scored as being from TSB; Table 2, Fig. 4A). PBE3 was most clearly distinguishable from other zones, driven by high Mn and Ba (Fig. 4A). PBE2 also had higher Mn

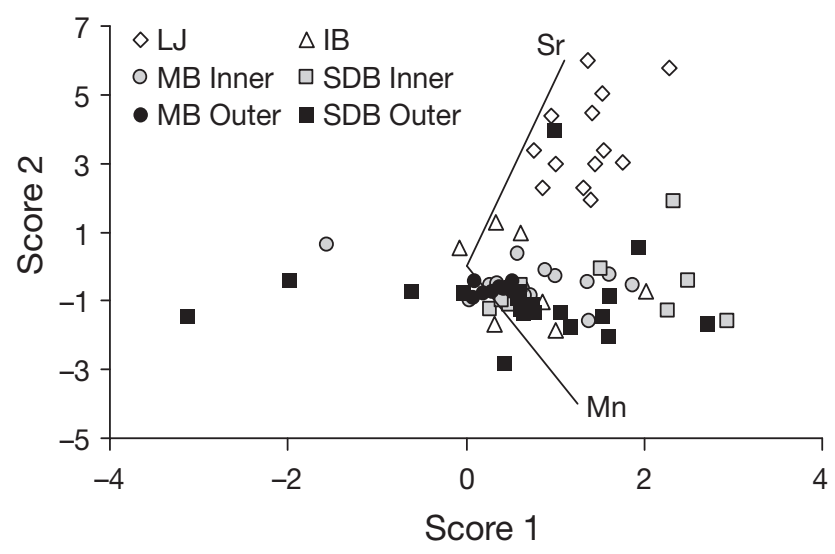

Fig. 3. Discriminant function analysis (DFA) scores of element:Ca ratios in otoliths of juvenile halibut collected during fall 2001 at sites in southern California. La Jolla (LJ) and Imperial Beach (IB) are sites along the exposed coast. Inner Mission Bay (MB Inner), outer Mission Bay (MB Outer), inner San Diego Bay (SDB Inner) and outer San Diego Bay (SDB Outer) are within embayments. DFA scores and discriminant functions are standardized by within variances and scaled to overlay scatterplots for the element ratios used to create algorithms. Vectors represent the relative contribution of each element ratio to the resulting group scores 
Table 1. Classification success matrix of assignments based on otolith signals from juvenile halibut collected from potential nursery habitats within the Baja California sites during 2002 and 2003, and the southern California sites during 2001. Rows list actual collection sites and columns catalog the predicted site of collection using discriminant function analysis algorithms, with replacement. Success rates are presented for individual sites in Baja California, as well as by sites grouped by habitat type: semi-exposed coast, port and estuary. For southern California, success rates are presented for individual sites (\% correct site), individual bays ( $\%$ correct bay) and zones within bays (\% correct zone)

\begin{tabular}{|c|c|c|c|c|c|c|c|c|c|}
\hline & TSB & Port En & PBE1 & PBE2 & PBE3 & $\%$ correct & $\begin{array}{c}\text { \% correct } \\
\text { habitat }\end{array}$ & & \\
\hline \multicolumn{10}{|c|}{ Baja California sites, 2002} \\
\hline TSB & 5 & 1 & 0 & 0 & 0 & 83 & 83 & & \\
\hline Port En & 2 & 3 & 2 & 0 & 0 & 43 & 43 & & \\
\hline PBE1 & 1 & 3 & 7 & 1 & 0 & 58 & & & \\
\hline PBE2 & 0 & 0 & 2 & 12 & 1 & 80 & 90 & & \\
\hline PBE3 & 0 & 0 & 0 & 1 & 12 & 92 & & & \\
\hline Total & 8 & 7 & 11 & 14 & 13 & 74 & 83 & & \\
\hline \multicolumn{10}{|c|}{ Baja California sites, 2003} \\
\hline TSB & 7 & 0 & 3 & 0 & 0 & 70 & 70 & & \\
\hline Port En & 2 & 6 & 1 & 0 & 1 & 60 & 60 & & \\
\hline PBE1 & 0 & 1 & 23 & 3 & 0 & 85 & & & \\
\hline PBE2 & 1 & 0 & 6 & 11 & 2 & 55 & 93 & & \\
\hline PBE3 & 2 & 1 & 0 & 2 & 15 & 75 & & & \\
\hline \multirow[t]{2}{*}{ Total } & 12 & 8 & 33 & 16 & 18 & 70 & 86 & & \\
\hline & $\mathrm{LJ}$ & IB & MB Inner & SBD Inner & MB Outer & SDB Outer & $\begin{array}{c}\% \text { correct } \\
\text { site }\end{array}$ & $\begin{array}{c}\% \text { correct } \\
\text { bay }\end{array}$ & $\begin{array}{c}\% \text { correct } \\
\text { zone }\end{array}$ \\
\hline \multicolumn{10}{|c|}{ Southern California sites, 2001} \\
\hline LJ & 13 & 0 & 0 & 0 & 0 & 0 & 100 & 100 & 100 \\
\hline IB & 0 & 1 & 5 & 2 & 1 & 1 & 10 & 10 & 10 \\
\hline MB Inner & 0 & 0 & 11 & 0 & 0 & 0 & 100 & $(\mathrm{MB}) 83$ & (Inner) 91 \\
\hline SBD Inner & 1 & 1 & 6 & 3 & 0 & 0 & 27 & (SDB) 44 & \\
\hline MB Outer & 0 & 0 & 8 & 2 & 5 & 3 & 28 & & (Outer) 44 \\
\hline SDB Outer & 1 & 0 & 7 & 4 & 1 & 8 & 38 & & \\
\hline Total & 15 & 2 & 37 & 11 & 7 & 12 & 49 & 63 & 61 \\
\hline
\end{tabular}

and $\mathrm{Ba}$ ratios than PBE1 and TSB. PBE1 fish were distinguishable from TSB juveniles by higher Ba. For $\mathrm{MB}$, discriminant algorithms were generated using $\mathrm{Mn}, \mathrm{Cu}, \mathrm{Sr}$ and $\mathrm{U}$ element ratios derived from otoliths of caged fish (Fig. 4B). Overall, specimens were assigned to caging sites with $76 \%$ accuracy (Table 2; compared to $34 \%$ in cases with caging sites randomized). Although only 2 fish from MB3 were analyzed for elemental composition, elemental signals were distinguishable from fish caged in other zones by high $\mathrm{Mn}$ and $\mathrm{Cu}$ (Fig. 4B). Fish from MB1 and MB2 exhibited overlapping signals, but all MB specimens were separated from the exposed site (SIO) due to relatively low $\mathrm{U}$, and high $\mathrm{Mn}$ and $\mathrm{Cu}$.

\section{Comparison of caged vs. wild-caught otolith microchemical signals}

There were no significant differences in $\operatorname{Mn}\left(F_{1,38}=\right.$ $0.092, \mathrm{p}=0.763)$ or Ba $\left(F_{1,38}=0.675, \mathrm{p}=0.417\right)$ con- centrations in recently deposited otolith material between caged and wild-caught fish collected in PBE (Fig. 5A,B). In contrast, there was a significant effect of embayment zone for both elements (Fig. 5A,B). Concentrations of $\mathrm{Mn}\left(F_{2,37}=6.904, \mathrm{p}=0.003\right)$ and $\mathrm{Ba}$ $\left(F_{2,37}=5.456, \mathrm{p}=0.009\right)$ in the otoliths of wild-caught and caged fish were higher in PBE3 than in PBE1 and PBE 2 (Fisher's post-hoc results: Mn, p $<0.001$ for PBE1 or PBE2 vs. PBE3; Ba, $p=0.038$ for PBE1 vs. PBE 3 and $p=0.004$ for PBE2 vs. PBE3). There was no interaction between factors for either $\mathrm{Mn}$ or $\mathrm{Ba}$. The spatial differences in the elemental composition of the otoliths of caged California halibut, coupled with the lack of differences in the signals obtained from wild and caged fish, implies that fingerprints obtained from outplanted fish can be used as a proxy for site-specific signals.

In $\mathrm{MB}$, none of the elements $\left(\mathrm{Mn}: F_{2,27}=2.219, \mathrm{p}=\right.$ $0.131 ; \mathrm{Cu}: F_{2,27}=1.745, \mathrm{p}=0.195 ;$ Sr: $F_{2,27}=0.854, \mathrm{p}=$ 0.438 ; and U: $F_{2,27}=0.216, \mathrm{p}=0.808$ ) included in the DFA of outplanted fish exhibited significant differ- 


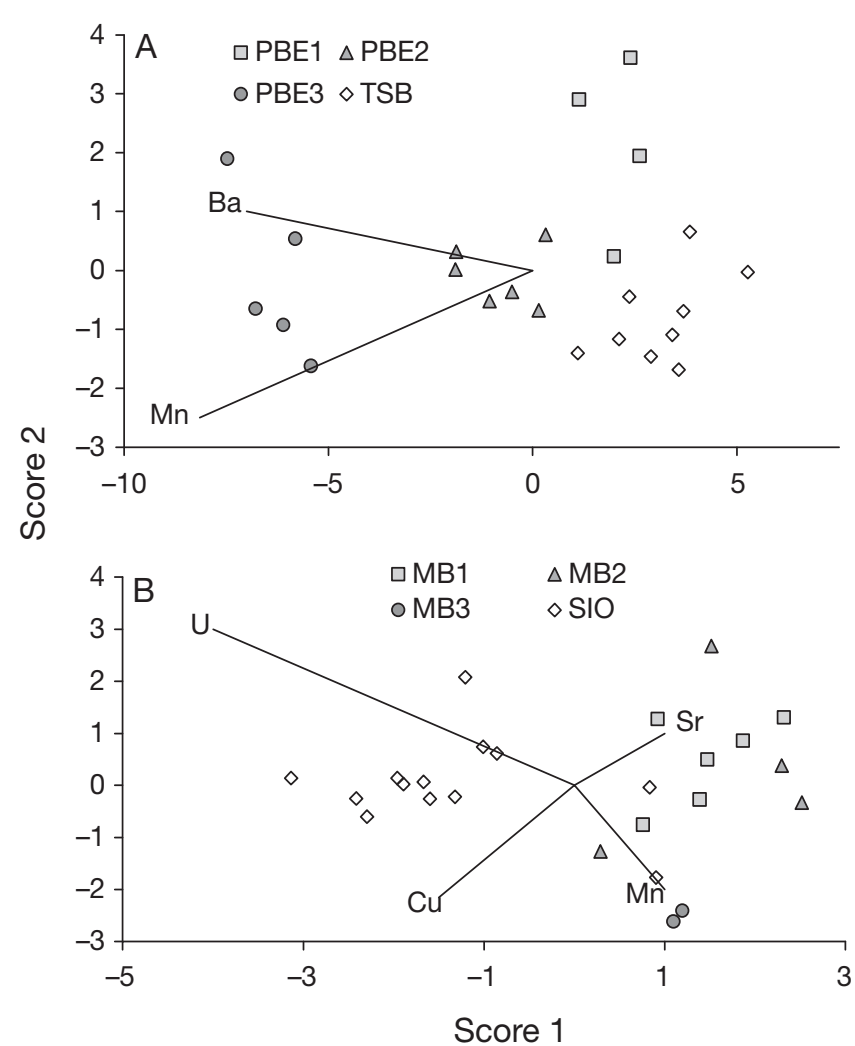

Fig. 4. Discriminant function analysis (DFA) scores of element:Ca ratios from the post-rostral margin of otoliths of caged juvenile halibut incubated in (A) outer, middle and inner Punta Banda Estuary (PBE1, PBE2 and PBE3, respectively) (TSB: embayment 'outlier') and (B) outer, middle and inner Mission Bay (MB1, MB2 and MB3, respectively) (SIO: embayment 'outlier'). Discriminant functions are standardized by within variances and scaled to overlay scatterplots, for the element ratios used to create the discriminant function analysis. Vectors represent the relative contribution of each element ratio to the resulting scores

ences among zones (Fig. 5C-F). However, $\mathrm{Mn}\left(F_{1,28}=\right.$ 8.459, $\mathrm{p}=0.008)$ and $\operatorname{Sr}\left(F_{1,28}=22.895, \mathrm{p}<0.001\right)$ concentrations differed significantly between caged and wild-caught fish (Fig. 5C,E). Concentrations of $\mathrm{Mn}$ were lower in the otoliths of caged fish in almost all zone-specific comparisons, while the opposite trend was observed for Sr. There was no interaction between factors. These results precluded the use of caged fish as signal proxies for tracking the small-scale movements of juvenile halibut within MB.

The fingerprints generated from caged fish in PBE were used to generate a reference set of zone-specific signals to chart the small-scale movements of juvenile halibut. Classification of 14 wild-caught individuals based on their otolith chemistry indicated that 8 individuals had moved among embayment zones. Of those, 5 appeared to have moved farther up the estuary (collected within all 3 PBE zones), including 1 fish that had immigrated from TSB to PBE1. Three other fish collected in PBE1 had moved down the estuary toward the mouth. The remaining 6 wildcaught fish had otolith chemistry that suggested they had remained near their capture location over a 2 mo interval.

\section{Nursery contribution of embayment zones}

Overall, PBE accounted for $82 \%$ (DFA) to $89 \%$ (classification trees) of the 27 sub-adults ( $\mathrm{n}=14$ and 13 individuals of 2 and $3 \mathrm{yr}$ old, respectively) that were captured in the TSB system and used to infer nursery contribution, while the semi-exposed coast (TSB) contributed $11 \%$ (DFA and trees) of recruits. Port En accounted for the remaining $0 \%$ (trees) to $7 \%$ (DFA) of advancing juveniles. All fish assigned to a nursery origin outside PBE, using either DFA or classification trees, were from the 2002 cohort. All production from the estuary was assigned to PBE1 and PBE2, regardless of the statistical analysis we used. No recruits we collected appeared to have occupied PBE3 during October to November of 2002 or 2003.

\section{DISCUSSION}

\section{Intra-embayment variability of otolith microchemistry}

We observed distinct chemical fingerprints among zones within embayments along 2 segments of the southern California, USA, and Baja California, Mexico, coastline. Thus, chemical fingerprints from these embayments and the adjacent exposed coast are better represented by a gradient rather than a step change between 2 habitat types. This is consistent with the role of estuarine/wetland systems, which are recognized as biogeochemical transformers located between terrestrial and marine ecosystems (Mitsch \& Gosselink 2000). In both $P B E$ and $M B$, fingerprints from the outer and middle reaches of the embayments were similar, while the innermost third was more distinct due to high $\mathrm{Mn}$ and Ba ratios (Figs. 2 \& 4). In addition to $\mathrm{Sr}$ and $\mathrm{Cu}$, which also regularly contributed to our ability to distinguish among zones, these elements appear to be valuable markers for defining small-scale fingerprints within coastal embayments with little to moderate freshwater influence (e.g. Gillanders \& Kingsford 2003, Hanson et al. 2004, Forrester 2005).

Ensuring that all significant fingerprints are included in the library of nursery signals is a necessary component of elemental fingerprinting studies that seek to deter- 
Table 2. Classification success matrix of assignments based on otolith signals from caged juvenile halibut in Baja California during the spring of 2004 and southern California during the fall of 2003. Rows list actual collection sites and columns catalog the predicted site of collection using DFA algorithms, with replacement. PBE1, PBE2 and PBE3 represent the outer, middle and inner sections of the Punta Banda Estuary, and TSB is an embayment 'outlier'. MB1, MB2 and MB3 correspond to the outer, middle and inner areas of Mission Bay, and SIO (Scripps Institution of Oceanography Pier) is an embayment 'outlier'

\begin{tabular}{|lccccc|}
\hline & PBE1 & PBE2 & PBE3 & TSB & \% correct \\
\hline Punta Banda & & & & & \\
PBE1 & 3 & 0 & 0 & 1 & 75 \\
PBE2 & 0 & 6 & 0 & 0 & 100 \\
PBE3 & 0 & 0 & 5 & 0 & 100 \\
TSB & 0 & 0 & 0 & 9 & 100 \\
Total & 3 & 6 & 5 & 10 & 96 \\
& & & & & \\
\hline \hline & & & & & \\
& MB1 & MB2 & MB3 & SIO & \% correct \\
\hline Mission Bay & & & & & \\
MB 1 & 3 & 3 & 0 & 0 & 50 \\
MB 2 & 0 & 3 & 1 & 0 & 75 \\
MB 3 & 0 & 0 & 2 & 0 & 100 \\
SIO & 1 & 0 & 1 & 11 & 85 \\
Total & 4 & 6 & 4 & 11 & 76 \\
\hline
\end{tabular}

mine past habitat utilization (Campana et al. 2000). Within southern California during the fall of 2001, intraembayment variability was as powerful in distinguishing habitat-specific otolith microchemical signals as interembayment variability (Table 1). Becker et al. (2005) reported similar zonation patterns in mussel shell chemistry in SDB and killifish collected from separate arms of San Quintin Bay in Baja California also exhibit unique chemical fingerprints (C. DiBacco \& D. Talley pers. comm.). Gillanders \& Kingsford (2000) examined if zones within southern Australia embayments (relatively similar in size and freshwater input to our study system) exhibited differences in trumpeter otolith microchemistry and found that nearby sites within estuaries exhibited significant variability in otolith signals. However, a related study on snappers found that intra-estuary variability was much less important than inter-estuary differences in otolith signals (Gillanders \& Kingsford 2003). Together, these data suggest that to better classify habitat signals along semi-arid and arid coastlines, future experiments could consider the coherence of (otolith) chemical signals within individual embayments (e.g. Fodrie \& Levin 2008), in addition to inter-embayment or temporal variability (e.g. Forrester \& Swearer 2002, Swearer et al. 2003).

Because there is very little freshwater inflow to PBE, $\mathrm{MB}$ or $\mathrm{SDB}$, unique signals in the inner reaches of these embayments are probably not the result of river-
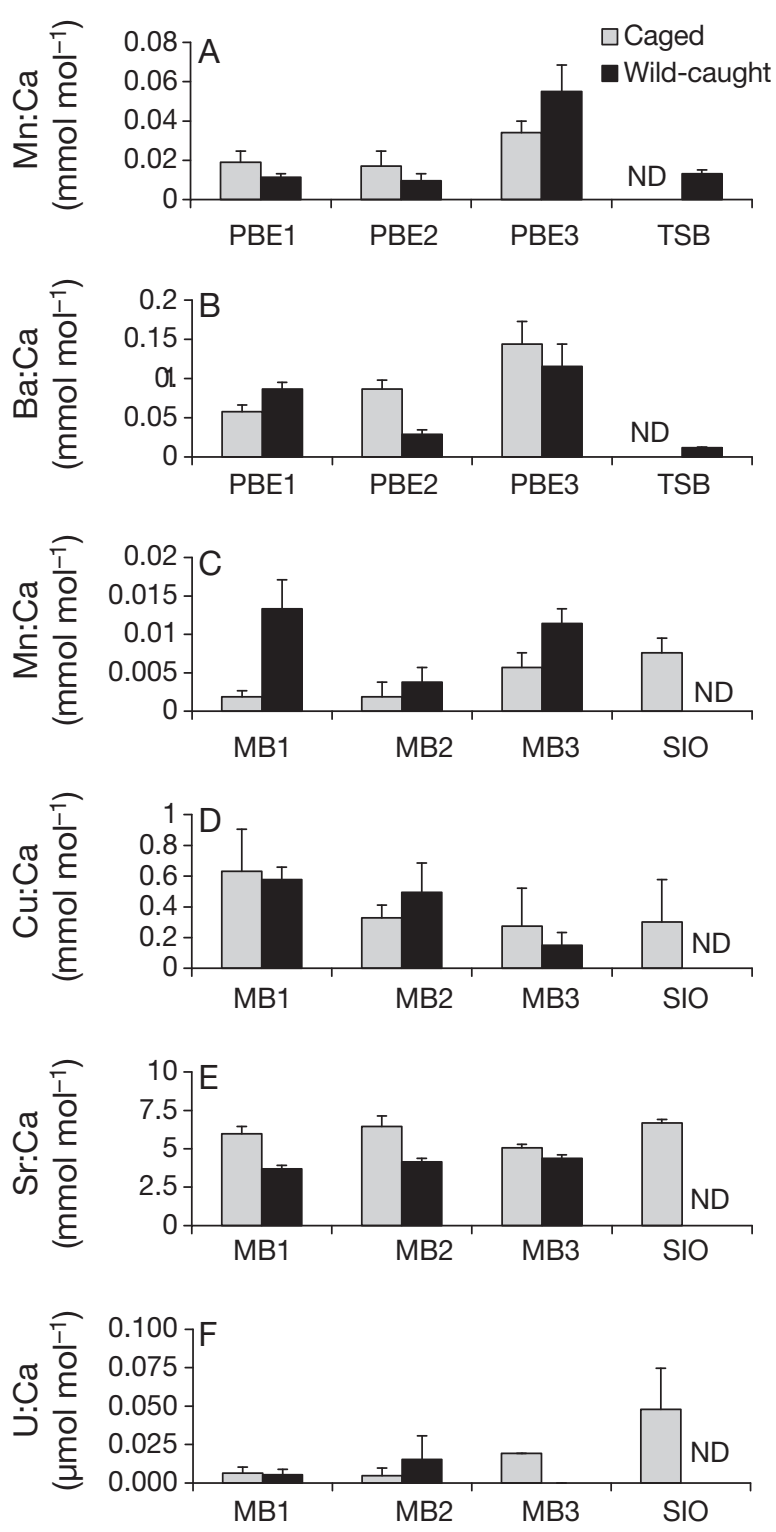

Fig. 5. Element:Ca ratios in otoliths of caged and wild-caught juvenile halibut collected within multiple embayment zones inside $(\mathrm{A}, \mathrm{B})$ Punta Banda Estuary $(\mathrm{PBE})$ and $(\mathrm{C}-\mathrm{F})$ for Mission Bay $(\mathrm{MB})$. Error bars represent $\pm 1 \mathrm{SE}$. ND = no data. Zones are as in Fig. 4

ine influence. Two other mechanisms may be responsible for the spatial gradients we observed in the otoliths of fish collected within these embayments: (1) sediment redox cycles and (2) extent of tidal excursions within embayments. Inside these embayments, Mn availability in near-bottom water is dominated by reduction-oxidation reactions in the sediments and overlying water column (J. Gieskes pers. comm.). In muddy, anoxic sediments typically found in the inner regions of embayments, the net transport of dissolved Mn is to the water column (Hanson et al. 1993), where 
it may become bioavailable for incorporation into otoliths. In contrast, the outer reaches of most embayments have better-oxygenated, sandy sediments that are constantly reworked by tidal flow. Within SDB, for example, there is a nearly linear gradient in Mn seawater concentration from the mouth $(<1 \mathrm{ppb})$ to the head (>30 ppb) (Esser \& Volpe 2002).

In the 3 embayments we studied, excursions of 'coastal' water during high tides typically reach only about half to two-thirds up the main axis of the embayment (see Pritchard et al. 1978 for PBE) and the inner reaches of these embayments usually have long residence times (Largier et al. 1997). For example, Largier et al. (2003) experimentally demonstrated that particles released in the inner reaches of MB (near our MB3 cages) typically remained within $500 \mathrm{~m}$ of the point of release over the course of several days. As a result, water masses in the innermost portions of embayments are likely to exhibit water properties and trace element loads (e.g. elevated $\mathrm{Cu}$ ) substantially different than those of relatively well-flushed areas near the mouth. Due to this circulation and high evaporation, PBE, MB and SBD all function as reverse estuaries during most of the year; highest salinities during our experiments were observed within PBE3 and MB3. The concentrations of Ba (Martin \& Wuenschel 2006) and Sr (Rooker et al. 2004, Martin \& Wuenschel 2006) in otoliths have both been shown to be positively associated with salinity. Therefore, we hypothesize that the microchemistry gradients we observed were driven largely by differences in salinity that resulted in elevated Ba and $\mathrm{Sr}$ in the otoliths of fish collected farther within these embayments.

\section{Comparison of caged vs. wild-caught fish otolith microchemical signals}

Outplanting fish in cages offers a novel but largely untested method for obtaining site-specific fingerprints to evaluate spatial variability in otolith elemental composition and infer recent fish movement (Elsdon \& Gillanders 2005, but see Chittaro et al. 2004). Kraus $\&$ Secor (2004) caged fish to demonstrate that uptake of $\mathrm{Sr}$ into otoliths was related to estuarine gradients in water chemistry and salinity. Forrester (2005) also employed caging to demonstrate that otoliths retain past environmental signatures after being transplanted to new locations. Our research attempted to directly compare the otolith chemistry of caged and wild-caught California halibut collected simultaneously. The recently deposited otolith material of caged juveniles in PBE exhibited chemical signals that did not differ significantly from those of wild-caught individuals captured in the same areas. This indicated that the otolith elemental composition of caged halibut could serve as a useful proxy for reconstructing the movement of fish among sites within PBE.

Based upon the 14 individuals we analyzed, we estimated that more than $50 \%$ of juvenile halibut (8 of 14) moved among embayment zones during the spring of 2004. PBE1 and PBE2 were connected to other zones both through emigration and immigration, while PBE3 was only connected through the immigration of fish towards the head of the estuary. These results suggest that some juvenile halibut move considerable distances (a few $\mathrm{km}$ ) over relatively short $(2 \mathrm{~m})$ time scales, while others remain within a specific area. S. Z. Herzka (unpubl. data) used mark-recapture techniques and length-frequency analyses to examine finescale movement patterns of juvenile California halibut in PBE. While the size distribution of juveniles varied over short time (weeks) and spatial $(<3 \mathrm{~km})$ scales, indicating some movement among zones and emigration from the estuary, all recaptured individuals $(n=6)$ were collected in the same zone of the estuary in which they were released. Hence, small-scale movement of juvenile halibut within embayments appears to be a complex process driven by numerous factors (such as food availability, the predator field, settlement and emigration) and warrants more detailed study.

In contrast to what was observed in PBE, caged and wild-caught juveniles from MB differed significantly in elemental composition (specifically $\mathrm{Mn}$ and $\mathrm{Sr}$ ). The differences in the otolith signals of caged and wildcaught fish from MB may be attributed to the more complex footprint of the system and the existence of chemical environments within MB that were not sampled (e.g. near boat marinas). Small-scale movements $(<1 \mathrm{~km})$ of juvenile halibut within MB immediately prior to our collection might have led us to compare caged and wild-caught fish that had been recording different environments in their otoliths. Thus, the caging effect we observed in MB may have been due to an interaction between steep spatial gradients in chemical environments and short-term fish movement. Similarly, Brown (2006b) generated habitat-specific fingerprints for English sole along the central California coastline, and observed that many of the fish that were misclassified by discriminant models had elemental concentrations that were intermediate between habitat types. She also hypothesized that some fish may have recently migrated between sites, or that fish regularly moved between habitat types and integrated both signals.

Alternatively, caging can alter flow, feeding rates or induce physiologic stress for fish (discussed in Phelan et al. 2000). These effects may interact with caging site to generate artifacts in the elemental signals observed in the otoliths of outplanted fish, and make the data 
useless in documenting smaller-scale (spatial or temporal) signal variability relevant for tracking wildcaught fish. In a recent study inside PBE, caged juvenile halibut exhibited substantially lower otolith growth rates and gut fullness than wild-caught individuals from the same locations (López-Rasgado 2006). Likewise, in our study, some caged fish exhibited a lack of distinguishable otolith growth increments or the complete absence of otolith growth. Previously, Martin \& Thorrold (2005) demonstrated that otolith precipitation rate and somatic growth of spot were correlated with otolith $\mathrm{Mg}$ : $\mathrm{Ca}$ (although they did not find a correlation with $\mathrm{Mn}: \mathrm{Ca}$ or Ba:Ca). Also, Miller et al. (2006) found that transition metals in cod otoliths could either preferentially bond $(\mathrm{Cu})$ or be excluded from $(\mathrm{Mn})$ the protein matrix. Since several of the otoliths we analyzed from caged fish $(\mathrm{n}=10)$ did not have visible increments, the balance between calcium carbonate and protein phases within those specimens may have been altered. Hence, altered feeding and growth, or physiological stress could have played a role in the $\mathrm{Mn}$ and Sr difference we observed between caged and wild-caught fish in $\mathrm{MB}$, although the effects of such factors on otolith chemistry are not fully understood (Campana 1999). However, in PBE we did not find significant differences in elemental ratios between caged and wild-caught fish, although we also recovered several caged fish without visible growth increments. Therefore, we think fish movement and chemical gradients within an embayment may be a more likely cause of the differences we observed in the elemental composition of caged and wild-caught fish in MB. Regardless, further calibration is needed before caging can routinely be used to generate proxies for habitat or site signals.

\section{Nursery contribution of embayment zones}

Within PBE, there were notable differences in the nursery role of embayment zones based on juvenile halibut movement and zone-specific contribution of recruits to older age classes. Elemental fingerprinting indicated that the large majority ( 82 to $89 \%$ ) of halibut production from nursery habitats within our Baja California study system originated from PBE during 2002 and 2003. By considering small-scale spatial variability in otolith fingerprints, we were also able to demonstrate that all of the sub-adults captured in TSB by local fishermen had occupied the middle and outer zones of the estuary. Conversely, there was no apparent contribution from the inner PBE to older halibut populations. According to Beck et al. (2001), nurseries are those habitats with above-average unit-area production of adults. Applying the nursery-role concept to
PBE would imply that the outer and middle zones of the estuary are important nurseries and that the innermost reaches of the system are not, even though juvenile halibut are found throughout the estuary (LópezRasgado 2006, S. Z. Herzka unpubl. data) and movement of some individuals is likely. However, our results are not conclusive in terms of the contribution of specific embayment zones, due to our relatively small sample size $(n=27)$. Furthermore, PBE3 might contribute a significant number of recruits, but only during years in which a certain set of environmental conditions are met (Kraus \& Secor 2005). Nevertheless, it is evident that the ability to evaluate habitat use and movement patterns over small spatial scales via elemental fingerprinting could have direct implications for the management of coastal embayments (see also Fodrie \& Levin 2008).

Acknowledgements. This work was funded by a California Department of Boating and Waterways agreement (03-106104), a National Science Foundation grant (OCE 0327209) and California SeaGrant rapid-response funds (R/F-117PD) to L. A. Levin; UCMEXUS, California Environmental Quality Initiative and National Science Foundation Graduate Research Fellowships to F.J.F. and by Basic Research Grant Number No. 39571 awarded to S.Z.H. by Mexico's Consejo Nacional de Ciencia y Tecnología (CONACyT). We appreciate the numerous volunteers and research technicians who helped during fieldwork and otolith preparation, especially A. Cleary. B. Deck and A. Deyhle of the SIO-UAF provided assistance with LA-ICPMS. We are indebted to L. A. Levin for detailed discussion regarding the manuscript and laboratory space. We thank J. Hunter, J Gieskes and 4 anonymous reviewers for comments on previous drafts.

\section{LITERATURE CITED}

Beck MW, Heck KL, Able KW, Childers DL and others (2001) The identification, conservation and management of estuarine and marine nurseries for fish and invertebrates. Bioscience 51:633-641

Becker BJ, Fodrie FJ, McMillan P, Levin LA (2005) Spatial and temporal variability in trace elemental fingerprints of Mytilid mussel shells: a precursor to invertebrate larval tracking. Limnol Oceanogr 50:48-61

Becker BJ, Levin LA, Fodrie FJ, McMillan PA (2007) Population connectivity patterns differ in closely related coastal bivalve species. Proc Natl Acad Sci USA 104:3267-3272

Breiman L, Friedman JH, Olshen RA, Stone CG (1984) Classification and Regression Trees. Wadsworth International Group, Belmont, CA

Brown JA (2006a) Using the chemical composition of otoliths to evaluate the nursery role of estuaries for English sole Pleuronectes vetulus populations. Mar Ecol Prog Ser 306:269-281

Brown JA (2006b) Classification of juvenile flatfishes to estuarine and coastal habitats based on the chemical composition of otoliths. Estuar Coast Shelf Sci 66:594-611

Campana S (1999) Chemistry and composition of fish otoliths: pathways, mechanisms and applications. Mar Ecol Prog Ser 188:263-297 
Campana S, Chouinard G, Hanson J, Frechet A, Brattey J (2000) Otolith elemental fingerprints as biological tracers of fish stocks. Fish Res 46:343-357

Chittaro PM, Fryer BJ, Sale PF (2004) Discrimination of French grunts (Haemulon flavolineatum, Desmarest, 1823) from mangrove and coral reef habitats using otolith microchemistry. J Exp Mar Biol Ecol 308:169-183

Elsdon TS, Gillanders BM (2005) Strontium incorporation into calcified structures: separating the effects of ambient water concentration and exposure time. Mar Ecol Prog Ser 285:233-243

Esser BK, Volpe A (2002) At-sea high-resolution trace element mapping: San Diego Bay and its plume in adjacent coastal ocean. Environ Sci Technol 36:2826-2832

Fodrie FJ, Levin LA (2008) Linking juvenile habitat utilization to population dynamics of California halibut. Limnol Oceanogr 53:799-812

Fodrie FJ, Mendoza G (2006) Availability, usage and expected contribution of potential nursery habitats for the California halibut. Estuar Coast Shelf Sci 68:149-164

Forrester GE (2005) A field experiment testing correspondence between trace elements in otoliths and the environment and for evidence of adaptation to prior habitats. Estuaries 28:974-981

Forrester GE, Swearer SE (2002) Trace elements in otoliths indicate the use of open coast versus bay nursery habitats by juvenile California halibut. Mar Ecol Prog Ser 241: 201-213

Fowler AJ, Campana SE, Jones CM, Thorrold SR (1995) Experimental assessment of the effect of temperature and salinity on the elemental composition of otoliths using solution-based ICPMS. Can J Fish Aquat Sci 52: 1421-1430

Gillanders BM (2002a) Connectivity between juvenile and adult fish populations: Do adults remain near their recruitment estuaries? Mar Ecol Prog Ser 240:215-223

- Gillanders BM (2002b) Temporal and spatial variability in elemental composition of otoliths: implications for determining stock identity and connectivity of populations. Can J Fish Aquat Sci 59:669-679

> Gillanders BM, Kingsford MJ (1996) Elements in otoliths may elucidate the contribution of estuarine recruitment to sustaining coastal reef fish populations of a temperate reef fish. Mar Ecol Prog Ser 141:13-20

Gillanders BM, Kingsford M (2000) Elemental fingerprints of otoliths of fish may distinguish estuarine nursery habitats. Mar Ecol Prog Ser 201:273-286

> Gillanders BM, Kingsford MJ (2003) Spatial variation in elemental composition of otoliths of three species of fish (family Sparidae). Estuar Coast Shelf Sci 57:1049-1064

Hanson PJ, Evans DW, Colby DR, Zdanowicz VS (1993) Assessment of elemental contamination in estuaries and coastal environments based on geochemical and statistical modeling of sediments. Mar Environ Res 36: 237-266

Hanson PJ, Koenig CC, Zdanowicz VS (2004) Elemental composition of otoliths used to trace estuarine habitats of juvenile gag Mycteroperca microlepis along the west coast of Florida. Mar Ecol Prog Ser 267:253-265

Kramer SH (1990) Distribution and abundance of juvenile California halibut, Paralichthys californicus, in shallow waters of San Diego County. Fish Bull Calif Dep Fish Game 174:99-126

Kramer SH (1991) Growth, mortality, and movements of juvenile California halibut (Paralichthys californicus) in shallow coastal and bay habitats of San Diego County, California. Fish Bull 89:195-207
Kraus RT, Secor DH (2004) Incorporation of strontium into otoliths of an estuarine fish. J Exp Mar Biol Ecol 302: 85-106

Kraus RT, Secor DH (2005) Application of the nursery-role hypothesis to an estuarine fish. Mar Ecol Prog Ser 291: 301-305

> Largier JL, Hollibaugh JT, Smith SV (1997) Seasonally hypersaline estuaries in Mediterranean-climate regions. Estuar Coast Shelf Sci 45:789-797

Largier JL, Carter M, Roughan M, Sutton D and others (2003) Mission Bay Contaminant Study. Report to the City of San Diego General Service Department. Scripps Institution of Oceanography, San Diego, CA

López-Rasgado FJ (2006) Evaluación del hábitat de crianza estuarino de juveniles de lenguado de California (Paralichthys californicus) con base en el crecimiento y la abundancia relativa. MS thesis. Centro de Investiagción Científica y de Educación Superior de Ensenada, Ensenada

Martin GB, Thorrold SR (2005) Temperature and salinity effects on magnesium, manganese and barium incorporation in otoliths of larval and early juvenile spot Leiostomus xanthurus. Mar Ecol Prog Ser 293:223-232

> Martin GB, Wuenschel MJ (2006) Effect of temperature and salinity on otolith element incorporation in juvenile gray snapper Lutjanus griseus. Mar Ecol Prog Ser 324: 229-239

Miller MB, Clough AM, Batson JN, Vachet RW (2006) Transition metal binding to cod otolith proteins. J Exp Mar Biol Ecol 329:135-143

Mitsch WJ, Gosselink JG (2000) Wetlands. John Wiley \& Sons, New York

Ortiz M, Huerta L, Hinojosa A (2003) Transporte de sedimento por tracción de marea en el Estero de Punta Banda, BC, México. GEOS 23:283-294

Pearce NJG, Perkins WT, Westgate JA, Gorton MP, Jackson SE, Neal CR, Chenery SP (1997) A compilation of new and published major and trace element data for NIST SRM 610 and NIST SRM 612 glass reference materials. Geostandard Newslett 21:115-144

> Phelan BA, Goldberg R, Bejda AJ, Pereira J and others (2000) Estuarine and habitat-related differences in growth rates of young-of-the-year winter flounder (Pseuopleuronectes americanus) and tautog (Tautoga onitis) in three northeastern US estuaries. J Exp Mar Biol Ecol 247:1-28

Posner M, Lavenberg RJ (1999) Movement of California halibut along the coast of California. Calif Fish Game 85:45-55

Pritchard DW, de la Paz Vela R, Cabrera-Muro H, FarrerasSanz S, Morales E (1978) Hidrografía física del Estero de Punta Banda Parte I: Análisis de Datos. Cienc Mar 5:1-23

Rooker JR, Kraus RT, Secor DT (2004) Dispersive behaviors of black drum and red drum: Is otolith $\mathrm{Sr}: \mathrm{Ca}$ a reliable indicator of salinity history? Estuaries 27:334-341

Secor D (1992) Application of otolith microchemistry analysis to investigate anadromy in Chesapeake Bay striped bass Morone saxatilis. Fish Bull (Wash DC) 90:798-806

Secor DH, Rooker JR (2005) Connectivity in the life histories of fish that use estuaries. Estuar Coast Shelf Sci 64:1-3

Secor DH, Dean JM, Laban EH (1991) Manual for otolith removal and preparation for microstructural examination. Belle W. Baruch Institute for Marine Biology and Coastal Research, 1991-01, Columbia, SC

> Secor D, Henderson-Arzapalo A, Piccoli PM (1995) Can otolith microchemistry chart patterns of migration and habitat utilization in anadromous fishes? J Exp Mar Biol Ecol 192:15-33

> Swearer SE, Forrester GE, Steele MA, Brooks AJ, Lea DW (2003) Spatio-temporal and interspecific variation in 
otolith trace-elemental fingerprints in a temperate estuarine fish assemblage. Estuar Coast Shelf Sci 56: 1111-1123

Thorrold SR, Jones CM, Campana SE, Mclaren JW, Lam JWH (1998a) Trace element signatures in otolith record natal river of juvenile American shad (Alosa sapidissima). Limnol Oceanogr 43:1826-1835

Thorrold SR, Jones CM, Swart PK, Targett TE (1998b) Accurate classification of juvenile weakfish Cynoscion regalis to estuarine nursery areas based on chemical signatures in otoliths. Mar Ecol Prog Ser 173:253-265

US Department of the Navy, Southwest Division and San Diego Unified Port District (2000) San Diego Bay Inte-

Editorial responsibility: Jon Hare, Narragansett, Rhode Island, USA grated Natural Resources Management Plan. Tierra Data Systems, Escondido

White JW, Ruttenberg BI (2007) Discriminant function analysis in marine ecology: some oversights and their solutions. Mar Ecol Prog Ser 329:301-305

Yamashita Y, Otake T, Yamada H (2000) Relative contributions from exposed inshore and estuarine nursery grounds to the recruitment of stone flounder, Platichthys bicoloratus, estimated using otolith Sr:Ca ratios. Fish Oceanogr 9:316-327

Zedler JB (1982) The ecology of southern California coastal salt marshes. US Fish and Wildlife Service, FWS/OBS81/54, Washington, DC

Submitted: January 11, 2007; Accepted: January 3, 2008

Proofs received from author(s): May 19, 2008 